\title{
@hannah_arendt: An Arendtian Critique of Online Social Networks
}

\begin{abstract}
New technologies in communications and networking have shaped the way political movements can be mobilized and coordinated in important ways. Recent uprisings have shown dramatically how a people can communicate its cause effectively beyond borders, through online social networking channels and mobile phone technologies. Hannah Arendt, as an eminent scholar of power and politics in the modern era, offers a relevant lens with which to theoretically examine the implications and uses of online social networks and their impact on politics as praxis. This paper creates an account of how Arendt might have evaluated virtual social networks in the context of their potency to create power, spaces and possibilities for political action. With an Arendtian lens it the paper examines whether these virtual means of "shared appearances" facilitate or frustrate efforts in the formation of political power and the creation of new beginnings. Based on a contemporary reading of her writings, the paper concludes that Arendt's own assessment of online social networks, as spheres for political action, would likely have been very critical.
\end{abstract}

The potency of online social networking sites, as channels of communication and a medium for people from all corners of the world to convene in a virtual realm and engage with shared ideas - political or otherwise - has increasingly become manifest in recent years. Not least since the protests in Moldova in 2009, the Green Revolution following the elections in Iran in the same year, and the Arab Spring uprisings of 2011, where the mobilization of bodies and voices to partake in various acts of revolt and revolution in Egypt, Tunisia, Syria and Libya was communicated through networks such as Twitter and Facebook, have people realized the potential for a transnational coming-together in a shared cause. Such online social networks have been hailed as the new conduits for political change and revolutions, empowering the oppressed and threatening oppressive regimes worldwide. They allow us to connect "without our voices, faces and bodies ${ }^{1}$ and overcome spatial and temporal limitations. Twitter and Facebook thus appear to serve as a global public realm within a virtual space, transcending geographic limitations and boundaries, thereby broadening the scope of possible political impacts considerably. Yet in terms of their capacity to actually bring about political change, online social networks have thus far not conclusively been proved to lead to lasting results. ${ }^{2}$

Online social networks are still fairly novel and somewhat ambiguous in their impact on politics and society. Some scholars argue that Web 2.0 platforms, including Facebook and Twitter, present 'unprecedented democratic possibilities for individual engagement

\footnotetext{
${ }^{1}$ Ayers, Michael D. and McCaughey, Martha. Cyberactivism: online activism in theory and practice. (New York: Routledge, 2003).

${ }^{2}$ For a thorough engagement with (in)effectiveness and consequences of social media as a tool for political change see Evgeny Morozov's The Net Delusion: How not to liberate the world (2011). See also Morozov, Evgeny. 'Facebook and Twitter are just places revolutionaries go'. The Guardian (March 7, 2011): Comment is free; available at http://www.guardian.co.uk/commentisfree/2011/mar/07/facebooktwitter-revolutionaries-cyber-utopians (2011)
} 
and empowerment', ${ }^{3}$, others suggest that Web 2.0 is far from being democratic and caters, rather, to a business structure of commoditization and state control. ${ }^{4}$ While studies on the subject proliferate, they can barely keep up with the many new uses and developments of and within these virtual spaces in all aspects of life. To date, research on the political effects and effectiveness of online social networks focuses predominantly on case- or country-specific empirical studies, often resulting in unhelpful 'dueling anecdotes,, or rely on algorithmic and statistical analyses. The outcomes are as manifold as the cases studied. Another challenge poses the temptation to consider political activities and behaviors in the online social environment as inherently new without taking into consideration established social patterns in the analyses. $^{6}$ Furthermore, thus far, scholarly inquests into this area are primarily conducted within the disciplines of computer and media studies or sociology. A welcome exception to this is technology scholar Evgeny Morozov's 'The Net Delusion' which seeks to dispel some of the myths about the political potency of social networks specifically, and the Internet as a political tool more generally. While sociological studies and media studies have made strong forays into analyses of online activism in terms of community building and identity shaping ${ }^{7}$, studies in political theory have remained sparse, and engagement with online social networks at the conceptual and theoretical level, as relevant for an (international) political theory context, is still somewhat underexplored. Nonetheless, and despite the ambivalences in research outcomes, online social media platforms have become crucial tools for "nearly all of the world's political movements ${ }^{8}$ and, with existing lenses offered by scholars of politics, we can observe and examine these rapidly and perpetually newly developing means of coming-together, and aim to make sense of the possibility of online social networks as tools for political power, in theory and praxis.

This paper opens a philosophically grounded investigation into the (im)possibility to create political power through online social networks, thereby adding a theoretical perspective grounded in political theory to an interdisciplinary debate. It is not intended to serve as a full assessment of the state of online activism and movements initiated through networks like Twitter and Facebook, but rather posits a theoretical examination to assess the potential for political power in these virtual global spheres. The work of Hannah Arendt lends itself well to such a theoretical exploration. Arendt has served as an important interlocutor for analyses of power and politics in the international context in recent years, positioning her at the centre of discussions on human rights, political theory and within the broader bounds of conceptions of power, politics and freedom in a global context. Her astute analysis of the human within her worldly setting as significant for politics is crucial here. For Arendt, it is the public sphere that facilitates the possibility of politics. With new platforms and tools available in an increasingly interconnected global arena, the virtual sphere becomes expanded and relevant for

\footnotetext{
${ }^{3}$ Veronica Barassi and Emiliano Trere. Does Web 3.0 come after Web 2.0? Deconstructing theoretical assumptions through practice. New Media \& Society 14(8) (2012) ; 1272

${ }^{4}$ Ibid

${ }^{5}$ Clay Shirky, The Political Power of Social Media - Technology, the Public Sphere and Political Change, Foreign Affairs 90 (1) (2011): 29

${ }^{6}$ Nils Gustaffson, The subtle nature of Facebook politics: Swedish social network site users and political participation New Media \& Society 14(7) (2012): 1112; David Campbell, Social Networks and Political Participation. Annual Review of Political Science 16 (10) (2013)

${ }^{7}$ See for example Manuel Castells. Networks of Outrage and Hope: Social Movements in the Internet Age. Cambridge: Polity Press, 2012; Paulo Gerbaudo. Tweets and the Streets: Social Media and Contemporary Activism. London: Pluto Press, 2012.

${ }^{8}$ Shirky, 'The Political Power of Social Media - Technology, the Public Sphere and Political Change', 30
} 
extending Arendt's analysis. Furthermore, it is Arendt's sharp insights into the 'individual as political agent', with the capacity for 'unpredictable and surprising acts of great political significance ${ }^{9}$ and her equally astute analysis of the mundane limitations for politics in modernity that render her such a useful lens for this discussion at the theoretical level. Arendt, in her relentless quest to understand the world, and her chief concern for the possibility of politics, would likely have been interested in the theoretical, if not practical dimensions of these new means for communication, mobilization and organization, specifically in a political context and through her we find an opening to consider anew the distinction between the social and the political as relevant for global politics. Her work on politics proper and the creation of power lends itself for the investigation of the (im)possibiliy for political action, and thus political change. It is her specific understanding of what politics is, her differentiation between action and behavior, her notion of the public sphere and her differentiation between the social and the political in the modern public sphere in particular that offers a useful way to conceptually engage with the notion of online social networks for the purpose of politics. Where Morozov highlights the misconceptions of online social media networks as a political tool, it is with Arendt, that we can attempt to illuminate why this perhaps might be the case. ${ }^{10}$ As such, I will first engage with the relevant concepts in Arendt's work in the context of this exploration: politics, power and plurality. The second section considers the character and some of the contemporary perceptions of online social networks, in as far as we can assess them - specifically, Twitter and Facebook. The third and final section contextualizes the effectiveness and implications of using social networks in the pursuit of political power and action with Arendt's theories on politics and power and reaches a conclusion as to why Arendt might have had her reservations toward the use of online social networks for political action.

\section{Politics, Power and Plurality in Arendt's Political Philosophy}

The work of Hannah Arendt is complex and full of categorizations and distinctions within which she seeks to comprehend the human as a political being that is situated within a modern environment. Her work is rich and manifold, covering a multitude of aspects that concern 'man' ${ }^{11}$ as a subject and object of politics and society in modernity. Specifically her conception of politics proper is useful for considering what political action means in modernity and why online social networks are perhaps unsuitable as public spheres to aid in the creation of political action proper and invoke concrete political outcomes. In order to clarify this argument, I will primarily draw on her seminal work, The Human Condition, as well as on her writings on violence and politics in the 1960s, and aim to engage with her perspectives on relevant categories, such as politics, power, plurality, and the public sphere.

The Human Condition presents a complex phenomenological analysis of human activity, set against the background of a range of historical features, causes and stages. ${ }^{12}$ It is a dense work, packed with categorisations and distinctions and Arendt herself had

\footnotetext{
${ }^{9}$ Anthony F. Lang and John Williams. Hannah Arendt and International Relations: Reading Across the Line (New York: Palgrave Macmillan 2008): 2.

${ }^{10}$ Evegeny Morozov, The Net Delusion: How not to liberate the world. (London: Penguin Books, 2011): 179-203.

${ }^{11}$ Throughout her work, Arendt predominantly refers to 'the human' as 'man'. In keeping with the Arendtian terminology, I will make use of the word man in the same sense where appropriate.

${ }_{12}$ Maurizio Passerin D'Entreves, Excerpt from “Hannah Arendt's conception of modernity”. In Hannah Arendt - Critical Assessments of Leading Political Philosophers, edited by Gareth Williams. (Abingdon: Routledge, 2007): 56
} 
considered it as a critical introduction to a continuing systematic investigation into political theory, which never transpired. ${ }^{13}$ Seeking to distinguish between the different types of human activity that provide the setting for politics in modernity, Arendt isolates three strands of the human condition upon which each human life and its unfolding relies: labour (zoe), the category concerned solely with life processes and necessities; work (poiesis), the act of fabrication, of making, to provide a common and stable world and physical arena for humans; and, finally, action (praxis), the activity relating to politics proper as conducted by free and equal men in the public sphere. In like manner, Arendt draws a distinction with regards to the spatial realms, within which these aspects of life - converging and separate - fall: the private realm, the social, and the public sphere.

\section{Politics Proper and Plurality}

Politics, as an intrinsically human action, is a fundamental concept in Arendt's work and it is important to note that her understanding of true politics, or politics proper, differs starkly from contemporary notions of what constitutes politics. Politics proper, for Arendt, belongs to the public realm. It relies on freedom and is made manifested through action and speech. What many political scholars and analysts of liberal democratic politics today consider to be dominant forms of politics - and specifically those forms of politics to which biopolitical analyses often refer - are, for Arendt a form of politics-as-management, akin to governmental administration and bureaucratic rule. This type of politics relates to a much greater extent to a professional dimension of politics, namely the administration, management and government of populations and their resources and is preoccupied with the distribution of political assets rather than the possibility for political engagement. Politics proper, in the Arendtian understanding, is in close keeping with the Greek understanding of the term: an activity that takes place among a group of free equals acting in a public sphere, facilitated through speech,. Political acts come to pass through action by unique individuals in a public sphere through consensus building. Such acts are never entirely predictable in their final outcomes and consequences. It is in the capacity for political action, that humans distinguish themselves from both 'beast and god', and as such is the 'exclusive prerogative of man'. ${ }^{14}$ Politics among humans is reliant on plurality, freedom and the existence of difference in a public sphere that provides the space for political action to unfold. In its lack of certain outcomes, political action is inherently and entirely contingent. ${ }^{15}$ In other words, in political action, the outcome can be aimed at but never be certain. This uncertainty, the contingent, is immanent to politics proper for Arendt, as it relies on action by humans and among humans, which is constantly in flux. 'Concrete realisations' in politics 'are constantly changing because we are dealing with other people who also have goals'. ${ }^{16}$ Such politics relies on a fundamental condition without which it could not transpire: plurality. And it is here that Arendt's differentiation of the social and political realm, and her lament of the conflation of the two in modernity, becomes salient. For Arendt, the social realm and the political realm have distinct attributes. The social occupies the nexus between the private and the public sphere and

\footnotetext{
${ }^{13}$ Margaret Canovan, Hannah Arendt - A Reinterpretation of Her Political Thought. (Cambridge: Cambridge University Press, 1995): xi

14 Hannah Arendt, The Human Condition (Chicago: The University of Chicago Press, 1998): 22

${ }^{15}$ Hannah Arendt, The Promise of Politics (New York: Random House/Schocken Books 2005): 193

${ }^{16}$ Ibid.,193
} 
is an inherently modern phenomenon. ${ }^{17}$ It is a normalising realm that is characterised by homogenisation and assortativity - like seeks like and is free to do so. But this homogenizing nature of the social has consequences for the nature of interactions. Through processes of 'levelling people into uniformity' ${ }^{18}$ differences are mitigated; the potential for spontaneous action becomes limited and is subsumed by behaviour, which is controlled and controllable. ${ }^{19}$ The problematic tension in the public sphere, that comprises both the social and the political, arises precisely if either the capacity for action is compromised or the condition of plurality is jeopardized.

In Arendt's conception, politics 'deals with the coexistence and association of different men'. ${ }^{20}$ The notion of difference is essential to the possibility of true politics in Arendt. As such, plurality is a key concept and serves as the 'basic condition for both action and speech'. ${ }^{21}$ Plurality refers to the very uniqueness of each human being, not merely in physical difference but in each human's unique narrative, experiences and initiatives. It is a duality of equality and distinction that characterises plurality. In Arendt's words: 'If men were not distinct, each human being distinguished from any other who is, was or will ever be, they would need neither speech nor action to make themselves understood'. ${ }^{22}$ Only in a context of different persons coming together to organise themselves by finding commonalities among an indeterminable plurality of unique aspects can political consensus emerge and the basis for political action be granted. And it is in this condition of a plurality of difference that equality is granted as the result of human organisation. While all aspects of the human condition are somehow related to the possibility of politics proper, plurality is the sine qua non condition and speech is the medium that allows men to interact and appear in their distinctiveness. And it is only in this coming together in difference, expressed and revealed through speech, that new formations, political or otherwise, can be brought about and new beginnings can emerge. In human togetherness within the public sphere, this disclosure through speech is key for Arendt, as each newcomer to the public sphere must primordially face the question: "who are you?"23 It is through speech that the "who" is revealed.

Speech and plurality are related; if there were no difference, the need for speech would be less pressing. Through speech, commonalities and differences can be mediated and moderated and it is speech that allows us to 'converse together rather than sound in chorus like sheep'. ${ }^{24}$ Political man is thus essentially constituted by speech. ${ }^{25}$ disclosing nature of speech is not entirely unproblematic. It can come to light only when humans are with one another - not for or against one another. It is in the latter use of speech that aims toward a specific end, rather than a goal, ${ }^{26}$ that speech can become 'mere talk' as instruments of propaganda, manipulation and political persuasion. ${ }^{27}$ Here, speech becomes un-tethered from action per se and gains relevance within a much broader spectrum than action. As Margaret Canovan highlights: 'Speech is presumably the

\footnotetext{
${ }^{17}$ Arendt, The Human Condition, 28; Hanna Fenichel-Pitkin, Attack of the Blob, (Chicago: University of Chicago Press 1998), 14

${ }_{18}$ Fenichel-Pitkin, Attack of the Blob, 14

${ }_{19}$ Arendt, The Human Condition, 40-41

${ }^{20}$ Arendt, The Promise of Politics, 94

${ }^{21}$ Arendt, The Human Condition, 175

${ }^{22}$ Ibid, $175-176$

${ }^{23}$ Ibid, 178

${ }^{24}$ Canovan, Hannah Arendt - A Reinterpretation of Her Political Thought, 131

${ }^{25}$ Ibid., 3

${ }^{26}$ Arendt makes a strong distinction between the terms 'end' and 'goal', whereby the former denotes a specific and defined teleological outcome, or end-state, while the latter refers to an aim.

${ }^{27}$ Arendt, The Human Condition, 180
} 
wider category, since we do a great deal of talking that could not be regarded as action social chat for instance'. ${ }^{28}$ Not all speech is concerned with disclosure, some also addresses issues of the worldly and tangible "in-between" people as well as of the web of relationships, as Arendt calls the intangible "in-between" that emerges in the interaction of men. ${ }^{29}$ Butler, in her insightful work on the performativity of speech, highlights this performative aspect of speech as having both, a political or a social dimension. Its various dimensions, whether that be in critique, in description, in advocacy or defence, may take on a political or a social dimension. Speech, in this sense, can take on many dimensions and in this, is playful, unpredictable and never fixed. ${ }^{30}$ But where speech engages with an interest for the wider public and within a public sphere, the politically performative dimension crystallises. This is closely related to the speech/action relationship in Arendt's work. Crucial here is that the outcome of speech, like the outcome of action, is always and inherently contingent. Where speech and action part ways, however, speech loses, for Arendt its disclosing (and thus politically constitutive) character and becomes performative in an instrumental dimension outside of politics proper. While, critics have noted that Arendt leaves her readers somewhat wanting with the exposition of how speech might be understood outside of politics, and how it can be conceptualized more accurately, ${ }^{31}$ for the purpose of this paper we can depart from the assertion that speech can and ought to constitute a performative and thus a political act - even in Arendt's complex account. For speech to transpire, the public realm as a sphere where humans gather is significant, as the next section will discuss.

\section{The (Global?) Public Sphere}

Underlying the categories indicated above is Arendt's articulation of man as inhabiting not merely a given world of natural elements but also a shared, human-made world of artefacts that corresponds to the act of fabrication, a key aspect of the human condition in Arendt's assessment. The function and role of a common and shared world that lends permanence to human life is of significance here. For her, the world is a product of the human aspect of work, it is created not solely for immediacy or consumption but for a temporal structure that exceeds the biological life cycle of one generation only. The world, as a tangible stage upon which human history unfolds through events, connects the plurality of men, while simultaneously holding space to ensure the freedom of men to engage in political action. In contrast to the contingent and changing nature of politics proper, this man-made shared world, and with it the public sphere, relies on a certain level of permanence. For Arendt, 'without the world into which men are born and from which they die, there would be nothing but changeless eternal recurrences, the deathless everlastingness of the human as of all other animal species'. ${ }^{32}$ Only through the existence of a shared artificial world do aspects of the human condition achieve meaning, life can gain a narrative and events can unfold. It is in such a narrativeproviding structure that humans can chose to reveal themselves and engage with others in the perpetual creation of new beginnings in a public sphere, actualise power and engage in politics proper.

\footnotetext{
${ }^{28}$ Canovan, Hannah Arendt - A Reinterpretation of Her Political Thought., 131

${ }^{29}$ Arendt, The Human Condition, 182

30 Judith Butler, Excitable Speech: A Politics of the Performative. (New York: Routledge, 1997)

${ }^{31}$ George Kateb, Hannah Arendt: Politics, Conscience and Evil. (New Jersey: Rowman \& Allanheld 1984): 14

${ }^{32}$ Arendt, The Human Condition, 97
} 
Just as with plurality, the public sphere is of key significance for Arendt. For her, public means 'everything that appears in public can be seen and heard by everyone and has the widest possible publicity'. ${ }^{33}$ Appearance in this public realm constitutes reality. "Public" signifies the world itself, in so far as it is common to all of us and distinguished from our privately owned place in it, in a coming together of human plurality, where people meet in a common ground, coming from different locations, from different positions. ${ }^{34}$ It is within and through this public sphere that the web of human relationships is created and perpetuated. It constitutes that which is literally inbetween people and with which most action and speech is concerned. ${ }^{35}$ The web of human relations is thus constituted by those aspects that exist and transpire in-between (inter-esse) men in the widest architectural, geographical and theoretical sense: the intangible and subjective but constitutive aspects of action and speech and the physical, worldly in-between of artificial objects. And it is in this web of relations that a person is revealed not merely as "what" they are but rather of "who" they are in their unique differentiation. Through acting within this web, humans can introduce "into the public realm something which, though intangible, is perfectly real and has consequences of its own. Every action is a new beginning and thus unexpected'. ${ }^{36}$ Given these broad characteristics in theory, at least, this sphere could potentially stretch as far as the globe, provided that this common world is truly common as a meeting ground.

This public sphere is preserved by another key aspect in the Arendtian account of political philosophy: power. In her words:

Power preserves the public realm and the space of appearance, and as such it is the lifeblood of the human artifice, which, unless it is the scene of action and speech, of the web of human affairs and relationships and the stories engendered by them, lacks its ultimate raison d'être. ${ }^{37}$

It is thus important to have a brief look at what constitutes power in the Arendtian account to understand this relationship more thoroughly.

\section{The Political Potential of Power}

In attempting to assess the actual potency of social networks on the creation of political action proper, we must consider Arendt's exposition of what constitutes power and what is political action more closely. For Arendt, power and political action are aligned in a number of aspects. Both can only be actualized in the context of human plurality, and both have an intrinsic and underlying contingency, whereby outcomes cannot be ascertained fully. Like political action, power depends on three key aspects: plurality, freedom and a shared space. Arendt's account of what constitutes power, how power functions and what its core characteristics are, is by no means uncontested. ${ }^{38}$ In many traditional and contemporary accounts of what constitutes power, power is understood in terms of command and obedience, whereby power often is conflated with strength,

\footnotetext{
${ }^{33}$ Ibid., 50

34 Ibid., 73

35 Ibid., 182

36 James Knauer, 'Motive and goal in Hannah Arendt's concept of political action'. In Hannah Arendt Critical Assessments of Leading Political Philosophers, edited by Gareth Williams. (Abingdon: Routledge 2006): 292

${ }^{37}$ Arendt, The Human Condition, 204

${ }^{38}$ Canovan, Hannah Arendt - A Reinterpretation of Her Political Thought; Paul Riceur, 'Power and Violence', in In Hannah Arendt - Critical Assessments of Leading Political Philosophers, edited by Gareth Williams. (Abingdon: Routledge, 2006)
} 
force and violence - specifically in the sovereign context. ${ }^{39}$ Arendt draws a strict distinction between these terms in order to properly define what constitutes power. ${ }^{40}$ For her, power is posited as the opposite of violence. ${ }^{41}$ In other words, power, for Arendt, is not power over humans but rather power of humans. As such, it comprises a number of core attributes. Firstly, power is a property that functions and is actualized but never contained or preserved. Power is thus not an instrument of force, strength or violence, by a sovereign or an individual, and to which individuals are subject, rather, power is generated among people - like energy - in plurality, and, in its permanent potentiality, can never be conserved but rather remains perpetually ephemeral - arising and disappearing only with the gathering and disbanding of people. Secondly, power is also boundless in Arendt's account. Its only limits are other people. ${ }^{42}$ In other words, there is no limitation to the scope of power other than by the number of interacting humans. Thirdly, for Arendt, power is entirely relational, taking place between subjects - it can neither be possessed nor stored. Specifically, power, Arendt asserts, 'corresponds to the human ability not to just act, but act in concert. Power is never the property of an individual; it belongs to a group and remains in existence only so long as the group keeps together'. ${ }^{43}$ In other words, power is always possible as a potentiality as long as people are able to band together in the formation of a group with a common or shared interest. Power can thus only exist for as long as this collectivity of powergenerating subjects remains an active collective. A disbandment of the collective lets power vanish.

The Arendtian concept of power is perhaps more closely related to a process of friction, by which power is generated but the level of this generation of power cannot be institutionalized permanently. In other words, power can only ever be "actualized", but never fully "materialized", ${ }^{44}$ and it always relies on the very plurality and differentiation of men. This means that power, for Arendt, can be generated at different locales and be maintained wherever people come together in a shared interest, including in the resistance to other locales of power. Here again we can distinguish Arendt's understanding of power as acknowledging the agency of subjects as able to change structures, to bring about something that is new and unknown - for better or for worse, locally and globally - in a cooperative dynamism. ${ }^{45}$ It is here, in this dynamic coming together to actualize power that Arendt sees the greatest potential for revolution. It is her assertion that the most lasting effects of a revolution can never be brought about through violence but are closely related to a shift of power. It is only when power (of a ruling or governing entity) has splintered and deteriorated that revolutions are possible (but not necessary). For Arendt, however, revolutions are never "made" 46 indicating that a contest of arms against arms does not constitute a revolution unless power (as the opposite of violence) plays an instrumental part in bringing about fundamental changes. In her words: 'Everything depends on the power behind the violence'. (emphasis added)

\footnotetext{
${ }^{39}$ Hannah Arendt, On Violence (Orlando: Harcourt Brace \& Company 1969), 40 -47; Canovan, Hannah Arendt - A Reinterpretation of Her Political Thought, 209-210; Kateb, Hannah Arendt: Politics, Conscience and Evil, 18

${ }^{40}$ Arendt, On Violence, 56; Patricia Owens, Between Wars and Politics - International Relations and the Thought of Hannah Arendt (New York: Oxford University Press 2007), 16-19; Canovan, Hannah Arendt A Reinterpretation of Her Political Thought

${ }^{41}$ Arendt, On Violence, 56

${ }^{42}$ Arendt, The Human Condition, 201

${ }^{43}$ Arendt, On Violence, 44

${ }^{44}$ Arendt, The Human Condition, 200

${ }^{45}$ Canovan, Hannah Arendt - A Reinterpretation of Her Political Thought, 214

${ }^{46}$ Arendt, On Violence, 48
} 
How then can we contextualise this Arendtian account of politics and power with the online social media networks that were hailed as fundamental in bringing about revolutions in Egypt and other Arab countries? And how would she assess such virtual networks in light of politics proper? In order to answer these questions, a brief look at contemporary perceptions of the nature and effectiveness of online social media for the creation of political action is in order.

\section{Twitter Bombs and Facebook Fads}

Network platforms such as Twitter, Facebook and YouTube reach an online community of millions and have been growing at an exponential rate. Twitter, with its microblogging format, has shot up to become one of the fastest growing Internet sites since its inception in 2006. Users can broadcast thoughts, ideas, texts, photos and can connect with other, likeminded individuals within the limits of 140 characters. As of 2012, the number of Twitter users just exceeded 500 million, with as many tweets being posted each week. ${ }^{48}$ Similarly Facebook, available in 70 languages, aims to connect friends worldwide and boasts over 1.19 billion active users as of September 2013. ${ }^{49}$ The majority of Facebook users are located in the United States, followed by Asia, Europe, Africa and Oceania. Both sites are among the most frequently visited Internet platforms on a daily basis worldwide - the possibilities for global connections and mobilization seem endless and chime somewhat with studies that have shown that an increased use of the Internet facilitates civic participation, not least, as Manuel Castells notes, through the raised communicative power it may generate. ${ }^{50}$ Specifically in the contemporary context, where a decline in political engagement among young people has been diagnosed and much documented ${ }^{51}$ the potential of social networks to reignite shared social and political interests seems potent. Indeed, as Baumgartner and Morris acknowledge, '[t]he Internet has been touted as a channel through which youth may become mobilized into politics and public affairs' ${ }^{52}$

Current research on the impact of online social networks on offline activity shows that interactions on some social media platforms not only reflect but also have the capacity to shape aspects of offline social networks. ${ }^{53}$ There is thus evidence to suggest that the online and offline realm should not solely be considered as separate entities but rather as areas of interaction that share intersections and characteristics. Nonetheless, research on

\footnotetext{
${ }^{47}$ Ibid., 49

48 Ingrid Lunden. "Twitter Passed 500M Users in June 2012, 140M of them in US; Jakarta, 'Biggest Tweeting' City. TechCrunch. July 30, 2012 Available at http://techcrunch.com/2012/07/30/analyst-twitterpassed-500m-users-in-june-2012-140m-of-them-in-us-jakarta-biggest-tweeting-city/

${ }^{49}$ Facebook Newsroom, Key Facts. Available at http://newsroom.fb.com/content/default.aspx?NewsAreald=22 (2013)

${ }^{50}$ Dhavan Shah, et al. "Connecting" and "disconnecting" with civic life: Patterns of Internet use and the production of social capital. Political Communication 18 (2) (2001): 141-162; Manuel Castells,

Communication, power and counter-power in the network society, International Journal of Communication 1, (2007): 257

51 Jody Baumgartner and Jonathan Morris, My FaceTube Politics - Social Networking Websites and Political Engagement of young Adults. Social Science Computer Review 201028 (1): 25

52 Ibid; Nils Gustaffson, The subtle nature of Facebook politics: Swedish social network site users and political participation. New Media \& Society 14 (7) (2012): 1111 - 1127

${ }^{53}$ Guadalupe Espinoza et al., Friending, IMing, and hanging out face-to-face: Overlap in adolescents' online and offline social networks. Developmental Psychology 48 (2) (2012): 356 - 368
} 
this topic is still young ${ }^{54}$ and studies into this subject have yielded mixed evidence and results. To date, opinions are divided as to whether the Internet has a positive effect on social participation and/or political participation or not. ${ }^{55}$ While some consider the mobilizing capacity of Facebook and Twitter an indispensable asset for political action in today's web-oriented social and political context, others maintain that it cannot lead to an increase in political action proper as the consequences of assembling in a virtual realm for a political cause rarely translates effectively into offline political action. In other words, it is not yet entirely clear in how far virtual online activism affects the reality that is to be acted upon in an offline context. For Morozov, it comes down to a statistical probability that some of the thousands of Facebook groups and causes will have some effect eventually. But it remains just that: a statistical probability rather than a causal relationship. ${ }^{56}$ While mobilization and group-formation is facilitated by highly connected online networks, their political efficacy may be somewhat overstated. ${ }^{57}$

The case of the tumultuous KONY2012 campaign, by the San Diego-based NGO Invisible Children, illustrates this issue and has most recently given new life to public debates over how effective and efficient Internet campaigns can be in terms of social activism and political action. The 30-minute campaign video - uncharacteristically long for a viral campaign - aired on March $5^{\text {th }}, 2012$ and was primarily aimed at raising awareness about the horrendous deeds of Ugandan rebel leader Joseph Kony, who has been indicted by the International Criminal Court for war crimes, by "making Kony famous". In an impassioned call for solidarity with the children of Uganda, the KONY2012 campaign called on political leaders, celebrities and citizens of the world to help 'stop' the brutal LRA rebel leader Joseph Kony. To do so, the video asks, people should pass the message on, get the KONY2012 kit (t-shirts, posters and wristbands) and mobilize on the $20^{\text {th }}$ of April 2012 to help bring Joseph Kony to justice for his cruel deeds. The video is laden with dramatic images and music and rich in emotive content. Within hours of being released, the video exploded onto the cyber-sphere, quickly becoming the most viral video ever. ${ }^{58}$ Some 70 million viewers had clicked on the campaign video on various online channels by day four. After only one week, the video had been mentioned in nearly 5 million tweets and an average of 1.3 million twitter messages about KONY2012 hit the ether per day in the three days following the release of the video. ${ }^{59}$ In terms of raising awareness, the video has been a success, owing the lion's share of this success to social media networks such as Twitter and Facebook. Along with the release of the KONY2012 video, the Internet virtually exploded with critiques of the video and the campaign itself, posted on Twitter, Facebook, blogs and a multitude of other online channels - a textbook case of the viral potency to mobilize people in the name of a social and political activism. Or is it?

\footnotetext{
${ }^{54}$ David Campbell, Social Networks and Political Participation. Annual Review of Political Science (2013) $16(10)$

${ }^{55}$ For positive accounts of the effect of the Internet on social and political participation see for example Shah, Kwak \& Holbert, 2001; Kestnbaum, Neustadl and Alvarez, 2000; Bucy and Gregson, 2001, for evidence indicating a negative relationship see for example Morozov 2011, Gladwell 2010, Nie, 2001; Margolis \& Resnick, 2000; Putnam 2000)

${ }_{56}$ Morozov. The Net Delusion: How not to liberate the world. 180.

${ }^{57}$ Ibid. 187

${ }^{58}$ David Campbell, Kony 2012:networks, activism and community, available on http://www.davidcampbell.org/2012/03/16/kony2012-networks-activism-community/ (Accessed on March 23, 2012)

${ }_{59}$ Pew Research Centre, The Viral Kony 2012 Video. Pew Research Center's Internet and American Life

Project; 2012 available at http://pewinternet.org/Reports/2012/Kony-2012-Video/Main-report.aspx
} 
Critics $^{60}$ have highlighted that the actual efficacy of such campaigns and the media through which they are communicated may simply not have the lasting effects a 'real world' activism campaign may have. In his analysis of social activism, Morozov points here to a disconnect between mobilization and organization as he notes: 'The newly gained ability to mobilize may distract us from developing a more effective capacity to organize." ${ }^{61}$ Not only is the call to action involving the click of a button questionable as a political act, it is in its sentiment also somewhat ephemeral and runs the risk of absolving those clicking from any further activity and political organisation. Furthermore, as David Campbell astutely observes, the KONY2012 video went viral 'because there was a pre-existing network of activists, built up over years through Invisible Children's media strategy who used social media to spread it far and wide, ${ }^{, 62}$ highlighting the role community plays in the dissemination of a message. The question remains: can online social networking campaigns truly create political power and political action or are they mere purveyors of fads and flashes that fall short of being able to constitute and create anything that could be considered political action? The lackluster aftermath of the KONY2012 campaign suggests the latter. The $20^{\text {th }}$ of April 2012 in which supporters of the KONY2012 campaign were called on to "cover the night" came and went without much visible and lasting impact. As Rory Carroll observes: 'The movement's phenomenal success in mobilizing young people online, [...], flopped in trying to turn that into real world actions'. ${ }^{63}$

In the wake of the Arab Spring uprisings, online social networks have been attributed as instrumental factors in the removal and / or overturn of dictatorships and bringing about democracy in its basic shape - as Morozov sardonically puts it: 'Tweets were sent. Dictators were toppled. Internet $=$ Democracy. QED. ${ }^{, 64}$ Indeed, several studies suggest that 'social networking now seems to be impacting political and social life across the globe', indicating that online social networks as such have affected political elections in a range of countries, from the US to Iran and China. ${ }^{65}$ Attia et al. claim that both Facebook and Twitter have played not only a peripheral but rather indeed a pivotal role in the uprisings in the Arab world, aligning their assessment with Wael Ghonim's claim that the 'power of the people is greater than the people in power' in Revolution 2.0. ${ }^{66}$ Egypt serves as the case in point. For Attia et al. it was the power of the online social networks that not only initiated but also facilitated the overthrow of the Mubarak regime in early 2011. In their assessment, the very roots of the revolution stem from demonstrations that are linked to the use of online social networks, based on the sheer numbers of networked potential participants. Furthermore, online social networks

\footnotetext{
${ }^{60}$ See for example Jack Bratich, The Rise of the Flashpublics - My Little Kony. Counterpunch.org available at http://www.counterpunch.org/2012/03/13/my-little-kony/ (Accessed on March 23, 2012); Campbell, Kony 2012:networks, activism and community; Max Fisher, The Soft Bigotry of Kony 2012. The Atlantic March 8, 2012 International available at http://www.theatlantic.com/international/archive/2012/03/the-soft-bigotry-of-kony-2012/254194/ ${ }^{61}$ Morozov. The Net Delusion: How not to liberate the world. 196.

62 Campbell, 'Kony 2012:networks, activism and community'

${ }^{63}$ Rory Caroll, Cover the Night fails to move from the internet to the streets. The Guardian 21 April 2012 World News Kony 2012 available at http://www.guardian.co.uk/world/2012/apr/21/kony-2012-campaignuganda-warlord. (Accessed on September 11, 2012)

${ }^{64}$ Evgeny Morozov, 'Facebook and Twitter are just places revolutionaries go'. The Guardian (March 7, 2011): Comment is free; available at http://www.guardian.co.uk/commentisfree/2011/mar/07/facebooktwitter-revolutionaries-cyber-utopians. (Accessed March 23, 2012).

${ }^{65}$ Ashraf Attia et al., Commentary: the impact of social networking tools on political change in Egypt's "Revolution 2.0". Electronic Commerce Research and Applications 10 (4), 2011: 369-374.

${ }^{66}$ Wael Ghonim, Revolution 2.0. (New York: Houghton, Mifflin Harcourt Publishing Company, 2012)
} 
enabled young Egyptians to 'freely communicate with each other and form groups to oppose Mubarak's totalitarian regime and government'. ${ }^{67}$

Online social networks, and Facebook here specifically, thus crystallized as a proxy realm for a free physical public space that had been otherwise occluded in a totalitarian regime. ${ }^{68}$ Within this proxy realm of communicative freedom, social network users in Egypt (and beyond) developed ties and relations with one another in solidarity for a shared struggle for change. ${ }^{69}$ This raises the question, how does such a virtual community emerge that may hold the potential to impact on social and political life within and across borders? What are the key features that constitute this proxy realm of freedom and that make it a potential conduit for the creation of power and political action? Several studies have shown that the very basis of how these virtual networks function is not much different than real-world social networks. A key factor here is trust - social, political or otherwise. ${ }^{70}$

When considering the political effectiveness of online tools such as Facebook and Twitter, however, it is important to keep in mind that they are primarily tools that promote social interaction and research indicates that social networks are primarily used, as the name suggests, for social purposes. They are largely built around 'weak ties ${ }^{, 71}$ In other words, group formation is made easier in social networks and doesn't require much 'social glue to begin with'. ${ }^{72}$ Facebook, specifically, aims to connect people that have already existing relationships, as peripheral as they might be, and where a distinct social association is already in place. Twitter, on the other hand, has the capacity to connect hitherto unassociated and unaffiliated people from a much wider spectrum and without the explicit demand of reciprocity. The ties, however, remain largely weak.

Studies indicate that social networks are chiefly used for entertainment and staying connected with existing affiliations. ${ }^{73}$ This seems reflected in the statistics on Twitter use as captured in a representative study conducted by Pear Analytics in 2009. The study found that the core content of Twitter feeds is somewhat personal comprising either conversational tweets $(37.5 \%)$ or "pointless babble ${ }^{74}(40 \%)$. This was followed by tweets that pass along information $(8.7 \%)$, self-promoting tweets $(5.7 \%)$ and only $3.6 \%$ appeared to relate to news - almost as many as spam tweets with $3.75 \%$ (Pear Analytics 2009). This distribution appears to confirm the prevalence of inter-personal relationships in online social networks. Such networks are thus rooted in personal connections (existing or new) and less likely to be organized by topic or issue. Baumgartner and Morris quote Danah Boyd in this context as they confirm:

\footnotetext{
${ }^{67}$ Attia et al., 'Commentary: the impact of social networking tools on political change in Egypt's "Revolution 2.0 "', 372

${ }_{68}$ Paolo Gerbaudo. Tweets and the Streets: Social Media and Contemporary Activism.

69 lbid

70 Ibid.; Baumgartner and Morris; Weiwu Zhang et al., The revolution will be networked: the influence of social networking sites on political attitudes and behaviour. Social Science Computer Review 28 (1) (2010): 75-92

${ }^{71}$ Malcom Gladwell, Small Change, The New Yorker October 4, 2010 Annals of Innovation available at http://www.newyorker.com/reporting/2010/10/04/101004fa fact gladwell?currentPage=1.; Mark Granovetter, The Strength of Weak Ties. American Journal of Sociology 78 (6) (1973): 1360 - 1380

72 Morozov. The Net Delusion: How not to liberate the world. 187.

73 Baumgartner and Morris, 27

${ }^{74}$ Pear Analytics' use of the term 'pointless babble' is somewhat disputed as too superficial (see Danah Boyd's work for more detail) and should perhaps more accurately be considered 'social grooming' - both terms, however, are chiefly within a non-political purpose and realm.
} 
Over the last decade, the dominant networked publics have shifted from being topically organized to being structured around personal networks. Most users no longer seek ... to discuss particular topics with strangers. Instead, they are hanging out online with people that they already know. ${ }^{75}$

This gravitating toward the known is essentially a feature of trust, as defined in Zhang et al. as 'expectations people have of each other, of the organizations and institutions in which they live and of the natural and moral social orders that set the fundamental understandings of their lives'. ${ }^{76}$ Trust is thus a crucial aspect for engagement within all social networks. It is primarily through networks of existing affiliations that trust is fostered and only as such can translate into the formation of politically inclined affiliations and, potentially action through communications, as Attia et al. state: 'When people communicate through social networking tools, they are likely to perceive the suggestions of people whom they know as credible and trustworthy'. ${ }^{77}$ Nonetheless, Baumgartner and Morris maintain that in the use of online social networks, "political engagement is at best an ancillary interest'. ${ }^{78}$ Zhang et al. suggest that political interest must already be existent in a network in order to be actualized in a social network and research has shown that there is a distinct difference between political activity online and political activity offline, in that the former does not necessarily translate into the latter. In Gladwell's words: 'weak ties seldom lead to high-risk activism' ${ }^{79}$

Social networking platforms as a source for political action per se might be limited, however, as sources for political information and political deliberation they appear to have considerable efficacy as Tumasjan et al. have shown in the context of social networks as indicators for election outcomes. ${ }^{80}$ Here, the relevance of homogeneity and heterogeneity of online social networks must be considered. Similar to offline social networks, online social networks tend toward homophily ${ }^{81}$ In other words, as Eguiluz et al and Zhang et al find in their studies, like tends to associate with like. This, in turn 'reinforces existing political disposition'. ${ }^{82}$ Furthermore, studies have shown that heterogeneity promotes participation in 'community forums and assorted political activities'. ${ }^{83}$

It is thus a coming together of likeminded people, typically with already existing political inclinations, that has the greater potential for political behavior, and it is through a more heterogeneously inclined social network that more plural information flow may transpire. Studies have shown thus, that there are greater networks among likeminded individuals, which, however, add little to stimulating debate among differing views. ${ }^{84} \mathrm{~A}$ recent Pew Research Center study has found that frequently networked friends disagree with friends on political opinion (only $25 \%$ indicated that they always agree with their friends), however $66 \%$ of those who disagree frequently will mostly ignore the views rather than respond. Interestingly, however, the same study has also found that $38 \%$ of online social network users have only through the use of

\footnotetext{
${ }^{75}$ Baumgartner and Morris, 27

${ }^{76}$ Zhang et al.

${ }^{77}$ Attia et al., 373

${ }^{78}$ Baumgartner and Morris, 27

${ }^{79}$ Gladwell

${ }^{80}$ Andranik Tumasjan et al., Election forecasts with Twitter: How 140 characters reflect the political landscape. Social Science Computer Review 29 (4) (2011): 402-418.

${ }^{81}$ Victor Eguiluz et al. Dynamics in online social networks. Eprint arXiv:1210.0808 (2012)

${ }^{82}$ Zhang et al., 79

83 Ibid.

${ }^{84}$ Baumgartner and Morris, 33
} 
virtual networks discovered that their views differ from those of their friends. ${ }^{85}$ In other words, political information relies on an already existent shared interest in politics for its dissemination and thus for power and political action to be decided on this virtual communications platform.

Online social networks, as the social space where power is determined, are thus by no means unproblematic as channels for engaging politically, not merely online but also offline. Questions remain as to whether they constitute an actual public sphere of political freedom or rather a (commercial) platform that has the capacity to influence its users beyond their notice. It remains obscure whether they thrive on plurality or have a homogeneous and homogenizing tendency, promoting behaviour, rather than action. In the context of the possibility for political action through online social networks, these aspects are crucial and it is here that I am turning again to the work of Hannah Arendt to assess in how far social networks are able to facilitate or frustrate efforts in the formation of political power and the creation of new beginnings. The next section will consider this question by contextualizing some of the key aspects in the formation of political action and power in Arendt's work with the nature of online social networks, specifically: plurality and the existence of a global public sphere.

\section{Arendt in Cybersphere, or what of Revolution 2.0?}

At first glance there appear to be a considerable number of characteristics constituting online social networks that naturally seem to fall into the strict categories that Arendt draws in the context of the human condition: they offer a public sphere within which an essentially plural (global) humanity can come together in difference, they function primarily through the medium of speech, which is the constitutive character for political action in the widest Arendtian sense and, in their character as a meeting place, carries the potential for people to actualize power in a political pursuit. But we would be amiss to take these congruencies on face value without looking at least a little more closely into the nuances.

\section{Twitter et al as a Global Public Sphere}

On a cursory reading it would seem that online social networks, as a human artifact, are a natural extension of what Hannah Arendt would approvingly consider as a humanmade world within which all aspects of the human condition can unfold. As discussed above, this human-made world is important for Arendt, as without it, humans are unlikely to be fully human unless they live in a duality of human-made worldly facets and the natural aspects of the earth as an environment. This human-made world of artifice is also of utmost significance to Arendt, as it provides, in quite a literal sense, the space (as in distance as well as in sphere) for humans to interact, take up different positions and reflect in plurality upon the common world from varying perspectives. It is only in this artificial world that men, in their togetherness, can gain a 'grasp of reality that nobody can achieve on their own' ${ }^{86}$ The artificiality here is crucial as it provides a structure upon which the human narrative of a shared world can unfold and, unlike the perpetual cyclicality and circularity of nature and life processes, creates shared meaning and ties to a common world. In the broadest sense, online social networks such as Twitter and Facebook, built by and on human-made artifice, do just that. They offer an

\footnotetext{
${ }^{85}$ Pew Research Center, Social Networking Sites and Politics. Pew Research Center's Internet and American Life Project; available at http://www.pewinternet.org/topics/Social-Networking.aspx.

${ }^{86}$ Canovan, Hannah Arendt - A Reinterpretation of Her Political Thought, 107
} 
artificial structure within which humans can trade different views, perspectives, and experiences and come to constitute new beginnings for a shared world. Just like the architectural aspects of a city within which men and women can gather, and through speech and action engage politically, Twitter and Facebook provide the virtual architectural structure within which unique persons can come together and reveal their "who", rather than their what. It serves as the inter-esse, the in-between, for speech and action upon which the web of human relationships is built. Furthermore, this virtual realm can serve as a proxy realm to resort to when the physic public sphere has been tyrannically restricted, as was the case in Egypt.

However, as with most things, it's not as simple as that.

For Arendt, a shared world of human-made artifice is much more cultural than technological. She relates the artifice to its original root - art - as a model for human fabrication, rather than the scientifically rooted constructions of technology. This is not entirely without controversy. In Canovan's words: 'the world she envisages and values [...] is more emphatically a world of cultural objects and milieux than of engineering' ${ }^{87}$ This stems in part from a deep skepticism toward an increasingly technocratic modernity that she saw as highly problematic in a political and social context. Furthermore, as a feature of a human-made world within which humans can fully unfold, such artifices as social networks don't meet one of the key requirements she stipulates for artifacts as constitutive of a shared and common world: durability of structures and artifacts. The ever-fluctuating and dynamic nature of online social networks, as they come and go remain essentially intangible as an architectural space for interaction. Some disappear as quickly as they appear. The rapid demise of Friendster and MySpace are a case in point. While online social networks, as platforms, share characteristics, it is uncertain whether they will constitute a meaningful sphere in five or ten years, as technology might produce yet entirely other spheres. The very novel and potentially ephemeral nature of Twitter and Facebook as proxy platforms render them unsuitable to be considered a durable stage on which men can interact in their plural uniqueness in the Arendtian sense. Arendt has something much more tangible and durable in mind when she considers this public sphere of human exchange and interaction and she would likely be critical of the temporary nature of this realm - it is erected for the here and now, the speed with which this realm develops, enters and leaves the realities of men makes it non-transcendent in terms of history, it is planned for the living only. This hinders the potential for politics. 'Without this transcendence into a potential earthly immortality, no politics, strictly speaking, no common world and no public realm is possible'. ${ }^{88}$

A further aspect might be problematic in this context: the actual scope and ability of virtual social networks to truly connect diverse people on a larger scale. Studies have shown that despite carrying unlimited potential for possible connections, both Facebook and Twitter actually appear to have immanent limitations that relate to our limitations as humans to connect - this pertains to the nature of these networks as social and takes us back to the "weak-ties" issue innate to Twitter and Facebook. As Chris Taylor highlights even online social networks tend toward tribalism. A study conducted by the University of Indiana has shown that Twitter users can only maintain between $100-200$ contacts in order to not get overwhelmed - despite being theoretically connected to

\footnotetext{
87 Ibid., 109

${ }^{88}$ Arendt, The Human Condition, 75
} 
thousands more users. In other words, Twitter users only converse meaningfully with a maximum of 100 - 200 of other users before it becomes simply too much. ${ }^{89}$ Furthermore, as the Pear Analytics study and other research shows, the number of people contributing within and to the global public Twittersphere is considerably less than those who consume the tweets, with $5 \%$ of Twitter users contributing $75 \%$ of the tweets. ${ }^{90}$ This raises the question as to how equal, egalitarian and political (in the Arendtian sense) this sphere can possibly be. It furthermore calls into question the condition of plurality in this context as the next section will discuss.

\section{Social or Political: The Problem with Plurality}

When considering online social networks as having the potential to create structures that facilitate political action it is important to remember that they are primarily social platforms, and not political ones. To conflate the two does not do justice to the potential efficacy (or lack thereof) of social networks as instruments. As we have seen earlier, the chief use of social networks is for entertainment and to connect with friends and acquaintances. When considering plurality in this context we must keep this distinction in mind. In society, people gravitate toward association, in a discriminatory (in the most literal sense of the word) manner, equality is not granted but rather people seek to associate in a homogenous way - like with like. This is reflected in recent studies on social networks and politics (see above). For Arendt, it is within this social realm that humans discriminate. This is based on her understanding of the individual uniqueness of each person as a comprehensive 'who', not merely a 'what'. This plurality in the public realm is, as I have outlined, the very cornerstone of politics in the public sphere for Arendt - it is not required for the social spaces. Only if we are to understand the social realm as a pre-political condition does her argumentation remain in line with her priority for plurality. In the social sphere, we tend to gravitate toward sameness, toward homophily. A social realm dominated by the drive toward association with the homogeneous thus must be primarily considered as not belonging to the political sphere per se and carries the potential to become the most treacherous realm in modernity as, in its extreme potential for conformism, difference is always in danger of becoming diminished, leaving those natural attributes that can not be made 'conform' an obvious parameter for inclusion / exclusion practices in societies. It is in the conflation, or perhaps the confusion, of the social with the political that an inherently exaggerated assumption of the political potential of social network lurks. In other words, when heterogeneity (or plurality) is not observed and homogeneity dominates, behaviour is substituted for action and true politics can thus not emerge. Given that, as we have seen earlier, social network users tend to have a more active exchange among a homogeneous group of people, the efficacy of social networks for political action remains doubtful. But even if plurality is not entirely ensured in the social network sphere - what of social networks as a channel to appear and reveal oneself to others through speech?

\section{Could Tweets be Considered Speech?}

\footnotetext{
${ }^{89}$ Bruno Concalves et al. Modeling Users' Activity on Twitter Networks: Validation of Dunbar's Number. PLoS ONE 6(8): e22656. doi:10.1371/journal.pone.0022656 (2011); Chris Taylor, Social networking utopia isn't coming, CNN Tech June 27, 2011, http://articles.cnn.com/2011-0627/tech/limits.social.networking.taylor 1 twitter-users-facebook-friends-connections? s=PM:TECH ${ }^{90}$ Lilian Weng et al., Competition among memes in a world with limited attention Scientific Reports doi:10.1038/srep00335. (2012) http://www.nature.com/srep/2012/120329/srep00335/full/srep00335.html\#/references ; Pear Analytics, Twitter Study (2009) http://www.scribd.com/doc/18548460/Pear-Analytics-Twitter-Study-August-2009
} 
As discussed above, speech is a key aspect of politics and political action in the Arendtian account. In her writing she frequently refers to speech as essential ${ }^{91}$ and as action as constituted in word and deed, however, the content of what constitutes speech as political action remains obscured and we could only guess at what Arendt might think of such truncated messages as tweets as speech acts. The online social networking sphere as a disembodied realm for humans to come together in a revelatory capacity would perhaps be appealing to Arendt, while the restrictive nature of confining oneself to 'speaking' within 140 characters would almost certainly have fallen on deaf ears in the Arendtian account. Given that the majority of tweets relate to personal, conversational or trivial issues, located entirely in a social sphere, it is likely that Arendt would have considered such content not to constitute revelatory speech in the political sense at all but rather as 'idle talk' ${ }^{92}$ Facebook as a more homogeneous medium is perhaps even less appropriate to consider as constituting true political speech acts in the Arentian sense. While 'speech' as Canovan and others have highlighted, is a much broader category than action, and could or may comprise social aspects, Arendt had no time for speech acts as self-expression ${ }^{93}$ as contributing anything to the creation of a shared world. It is precisely this aspect of self-expression that is central to the use of Facebook and, to a degree, Twitter. As Hart et al. write: 'The aspect of representing oneself to other people in a social situation [is] a key feature within Facebook, which allows its users to express themselves through the creation of personal profile that can be shared with friends'. ${ }^{94}$ This suggests that activities on social networks might largely be introspective and hedonistic endeavors that have little, if nothing to do with establishing a shared and common world. The focus is no longer a being-with-others, but rather a broadcasting-to-others that defines such types of one-way communication.

\section{The Problem with Virtual Power}

As with the public sphere, there are some obvious matching features of virtual social networks in light of Arendt's understanding of what constitutes power. Online social networks are inherently contingent, exchanges are ephemeral and power created through and within social networks is actualized and appears to last only momentarily. The seemingly unlimited scope of the social network in cybersphere appears to be boundless, supporting the boundlessness of power as such. Activity generated through such networks appear to have a basis in potentiality as well. They adhere to dynamics that are in themselves contingent and ephemeral. During high profile events, such as sporting events or a celebrity misfortune, Twitter use skyrockets, causing servers to crash and online services to slow down. Twitter use, for example, shot up disproportionately when the news of Osama Bin Laden's death broke. Similarly, as we have seen with the KONY2012 campaign, activity can flare up in flurries, raising awareness and perhaps mobilizing people to become engaged and aware in a relatively short period of time, yet dissipating almost as quickly as the phenomenon occurred.

The fundamental role of online social networks in the creation of popular power for political revolutions may not entirely be clear at this stage. It remains questionable

\footnotetext{
${ }^{91}$ Canovan, Hannah Arendt - A Reinterpretation of Her Political Thought; Kateb, Hannah Arendt: Politics, Conscience and Evil

${ }_{92}$ Arendt, The Human Condition, 208

${ }_{93}$ Kateb, Hannah Arendt: Politics, Conscience and Evil, 10; Arendt, The Human Condition, 323

94 Jennifer Hart et al., Exploring the Facebook experience: a new approach to usability. Paper presented at 5th Nordic Conference on Human-computer Interaction: Building Bridges October 20-22, 2008. ACM New York pages 471 - 474
} 
whether online activity in the political context can possibly translate into veritable offline activity and therein lies the crux and misunderstanding in the use of social networks for political activity. As Jack Bratich writes in the context of the KONY2012 campaign:

Drawing on the power of social media to mobilize sentiment and bodies (a la the Arab Spring) K-12 mutates the transnational socially-networked public opinion from a year ago in a few ways. First, it wants to turn information into action, getting US users not only to share their outrage and pass along info, but also to get out into the streets. ${ }^{95}$

What transpires is then essentially not a coming together of equals in a political cause but rather a flashpublic, whereby the entertainment value and the initial 'great ecstasy of fraternity' ${ }^{96}$ outweigh the actual political act. Bratich explains this phenomenon: 'The flash of the flashpublic is a quick mobilization of attention and sharing towards a predefined political objective'. ${ }^{97}$ This flashpublic relies, to a certain extent on both, homogeneity and mimicry, thus occluding the possibility for politics proper as Arendt would have it. With its call to action, the KONY2012 flashpublic campaign resembles, according to Bratich, a 'funhouse mirror, grotesquely exaggerating the proportions of the body politic involved.' Why, Bratich asks, 'Because the mobilization for action is one already determined as an instrument for someone else's goals'. ${ }^{98}$

\section{Conclusion}

Despite the ambiguity of the benefit of online social networks for political action, it has become increasingly clear that such networks and the political campaigns that are run on social networking platforms can facilitate the information flow related to political events and help coordinate political mobilization campaigns. However, they are, and can only be by their immanent limitations, one aspect, one tool in the efforts to mobilize for politics. There is a difference between using social networks such as Twitter and Facebook for planning a revolution and executing a revolution. The former can be facilitated through such network, the latter proves for many to be a delusion. ${ }^{99}$ As Morozov argues, while the Internet broadly is instrumental (in the most literal sense) for bringing about power and revolutions, it is merely that: an instrument, a tool. Political change, on the other hand 'continues to involve many painstaking, longer-term efforts to engage with political institutions and reform movements' ${ }^{100}$ And for that, as Arendt reminds us, it would require more permanent structures as a public sphere than the virtual realm has to offer. The regime change in Egypt, for example, was initiated by long-term campaigns of offline communities that sought to mobilize a heterogeneous civic population by going door-to-door, village-to-village. Looking at these online structures for the possibility of politics through an Arendtian lens allows us to engage conceptually with some of the characteristics of online social networks and how they might affect the possibility for politics, rather than rely on specific case analyses and anecdotal evidence.

\footnotetext{
95 Jack Bratich, The Rise of the Flashpublics - My Little Kony. Counterpunch.org available at http://www.counterpunch.org/2012/03/13/my-little-kony/ (2012)

${ }_{96}$ Arendt, On Violence, 50

${ }_{97}$ Bratich. 'The Rise of the Flashpublics - My Little Kony'

${ }^{98}$ Ibid.

99 Morozov, 'Facebook and Twitter are just places revolutionaries go'

100 Ibid.
} 
Arendt, having contributed her very critical opinion on technology at a conference on cyberculture in 1964 might have found an appreciation for the medium as a political channel to coordinate people in a contemporary context and she would likely have found some redeeming aspects in online social networks in that they might serve as a proxy realm in which freedom may come to pass and humans can engage in speech acts for the exchange of information and appearances, - but within limits. Online social networks provide primarily a realm that is characterized by homogeneity and homophily by its very social nature. As a public sphere that binds humans in a shared and common world and that facilitates politics proper the virtual realm is insufficient. As it relates to the social aspects of human interaction much more directly than the political realm, such networks would have held her appreciation and interest only briefly and in the context of revolutions Arendt would likely have wholeheartedly concurred with Morozov that revolutionaries are not made through online social networks but rather: 'Facebook and Twitter are just places revolutionaries go'. ${ }^{101}$

\section{Bibliography}

Arendt, Hannah. On Violence. Orlando: Harcourt Brace \& Co, 1969.

—. The Human Condition. Chicago: University of Chicago Press, 1998.

—. The Promise of Politics. New York: Random House / Schocken Books, 2005.

Attia, Ashraf M., Nergis Aziz, Barry Friedman, and Elhusseiny F Mahdy. "Commentary: the impact of social networking tools on political change in Egypt's "Revolution 2.0"." Electronic Commerce Research and Applications 10, no. 4 (2011): 369-374.

Ayers, Michael D, and Martha Mccaughey. Cyberactivism: online activism in theory and practice. New York: Routlegde, 2003.

Barassi, Veronica and Trere, Emilio. "Does Web 3.0 come after Web 2.0?

Deconstructing theoretical assumptions through practice." New Media \& Society 14, no. 8 (2012)

Baumgartner, Jody, and Jonathan Morris. "My FaceTube Politics - Social Networking Websites and Political Engagement of young Adults." Social Science Computer Review 28, no. 1 (2010): 24-44.

Bratich, Jack. The Rise of the Flashpublics - My Little Kony. 03 13, 2012. http://www.counterpunch.org/2012/03/13/my-little-kony (accessed 03 23, 2012).

101 Ibid. 
Bucy, Erik P., and Kimberly S. Gregson. "Media Participation: A legitimizing mechanism of mass democracy." New Media \& Society 3, no. 3 (2001): 357 - 380.

Butler, Judith. Excitable Speech: A Politics of the Performative. New York: Routledge, 1997.

Campbell, David. Kony 2012: networks, activism and community. 03 16, 2012. http://www.david-campbell.org/2012/03/16/kony2012-networks-activism-community (accessed 03 23, 2012).

Campbell, David. "Social Networks and Participation." Annual Review of Political Science 16, no. 10 (2013).

Canovan, Margaret. Hannah Arendt - A Reinterpretation of Her Political Thought. Cambridge: Cambridge University Press, 1995.

Carroll, Rory. "Cover the Night fails to move from the Internet to the streets." The Guardian, 04 21, 2012.

Castells, Manuel. Networks of Outrage and Hope: Social Movements in the Internet Age. Cambridge: Polity Press, 2012.

Castells, Manuel. "Communication, Power and Counter-point in the Network Society." International Journal of Communication 1 (2007): 238-266.

D'Entreves, Maurizio Passerin. "Excerpt from 'Hannah Arendt's conception of modernity." In Hannah Arendt - Critical Assessments of Leading Political Philosphers, by Gareth Williams. Abingdon: Routledge, 2006.

Eguiluz, Victor M., Przemyslaw A. Grabovicz, and Jose J. Ramasco. "Dynamics in online social networks." Eprint arXiv:12100808. 2012.

Espinoza, Guadalupe, Stephanie M. Reich, and Kaveri Subrahamanyam. "Friending, IMing and hanging out face-to-face: Overlap in adolescents' online and offline social networks." Developmental Psychology 48, no. 2 (2012): 356-368.

Facebook Newsroom. Facebook Newsroom - Key Facts. 2012. http://newsroom.fb.com/content/default.aspx?NewsAreald=22. (accessed 03 23, 2012).

Fenichel-Pitkin, Hanna. Attack of the Blob. Chicago: University of Chicago Press, 1998.

Fisher, Max. "The Soft Bigotry of Kony2012." The Atlantic, 03 09, 2012.

Gerbaudo, Paolo. Tweets and the Streets: Social Media and Contemporary Activism. London: Pluto Press, 2012.

Ghonim, Wael. Revolution 2.0. New York: Houghton, Mifflin Harcourt Publishing Company, 2012.

Gladwell, Malcom. "Small Change." The New Yorker, 10 4, 2010.

Goncalves, Bruno, Nicola Perra, and Alessandro Vespignani. "Modelling Users' Activity on Twitter Networks: Validation of Dunbar's Number." PloS ONE 6, no. 8 (2011): ): e22656. doi:10.1371/journal.pone.0022656 .

Gordon, Neve. "On Visbility and Power: An Arendtian Corrective of Foucault." Human Studies 25 (2002): 125-145. 
Granovetter, Mark S. "The Strength of Weak Ties." American Journal of Sociology 78, no. 6 (1973): 1360-1380.

Gustaffson, Nils. "The subtle nature of Facebook politics: Swedish social network site users and political participation." New Media \& Society 14, no. 7 (2012): 1111-1127.

Hart, Jennefer, Charlen Ridley, Faisal Taher, Corina Sas, and Alan Dix. "Exploring the Facebook experience: a new approach to usability." New York: ACM, 10 20-22, 2008. 471-474.

Kateb, George. Hannah Arendt: Politics, Conscience and Evil. New Jersey: Rowman \& Allanheld, 1984.

Knauer, James. "Motive and goal in Hannah Arendt's concept of political action." In Hannah Arendt - Critical Assessments of Leading Political Philosophers, by Gareth Williams. Abingdon: Routlege, 2006.

Langer, Anthony F. and Williams, John. Hannah Arendt and International Relations: Reading Across the Line. New York: Palgrave MacMillan, 2008).

Lunden, Ingrid. Twitter Passed 500M Users InJune 2012, 140M of them in US; Jakarta 'Biggest Tweeting' City. TechCrunch. July 30, 2012. Available on http://techcrunch.com/2012/07/30/analyst-twitter-passed-500m-users-in-june-2012140m-of-them-in-us-jakarta-biggest-tweeting-city/

Margolis, Michael, and David Resnik. Politics as Usual: The 'Cyberspace Revolution'. Thousand Oaks: Sage Publications, 2000.

Morozov, Evgeny. The Net Delusion: How not to liberate the world. London: Penguin Books, 2011.

Morozov, Evgeny. "Facebook and Twitter are just places revolutionaries go." The Guardian, 03 07, 2011.

Nie, Norman H., and Sunshine Hillygus. "Education and democratic citizenship." In Making good citizens: Education and civil society, by Diane Ravitch and Joseph Viteritti. New Haven: Yale University Press, 2001.

Owens, Patricia. Between Wars and Politics - International Relations and the Thought of Hannah Arendt. New York: Oxford University Press, 2007.

PEAR ANALYSTICS. "Twitter Study - August 2009." http://www.scribd.com/doc/18548460/Pear-Analytics-Twitter-Study-August-2009 (accessed 03 23, 2012).

PEW REsearch Centre. Social Networking Sites and Politics. Internet and American Life Project, Pew Research Centre, Pew Research Centre, 2012.

Putnam, Robert D. Bowling alone: the collapse and revival of American community. New York: Simon \& Schuster, 2000.

Riceur, Paul. 'Power and Violence', In Hannah Arendt - Critical Assessments of Leading Political Philosphers, by Gareth Williams. Abingdon: Routledge, 2006

Robinson, John P., Meyer Kestnbaum, Alan Neustadtl, and Anthony Alvarez. "Mass media use and social life among Internet users." Social Science Computer Review 18 (2000): 490-501. 
Shah, Dhavan V., Nojin Kwak, and Lance R. Holbert. "'Connecting' and 'disconnecting' with civic life: Patters of Internet use and the production of social capital." Political Communication 18, no. 2 (2001): 141-162.

Shirky, Clay. "The Political Power of Social Media - Technology, the Public Sphere and Political Change." Foreign Affairs 90, no. 1 (2011): 28-41.

Taylor, Chris. Social networking utopia isn't coming. 06 27, 2011. http://articles.cnn.com/2011-06-27/tech/limits.social.networking.taylor_1_twitter-usersfacebook-friends-connections?_s=PM:TECH (accessed 03 23, 2012).

Tumasjan, Andranik, Timm O. Sprenger, Philip G. Sandner, and Isabell M. Welpe. "Election forecasts with Twitter: How 140 characters reflect the political landscape." Social Science Computer Review 29, no. 4 (2010): 402-418.

Weng, Lilian, Sandro Flammini, Alex Vespignani, and Fil Menczer. "Competition among memes in a world with limited attention." Nature.com. 2012.

http://www.nature.com/srep/2012/120329/srep00335/full/srep00335.html\#/references (accessed 03 23, 2012).

Zhang, Weiwu, Thomas J. Johnson, Trent Seltzer, and Shannon Bichard. "The revolution will not be networked: the influence of social networking sites on political attitudes and behaviour." Social Science Computer Review 28, no. 1 (2010): 75-92. 